Collection Building, 2001, Volume 20, No.2, pp.73-79

ISSN: 0160-4953

DOI: $10.1108 / 01604950110388707$

http://www.emeraldinsight.com/

http://www.emeraldinsight.com/journals.htm?issn=0160-4953

http://www.emeraldinsight.com/journals.htm?issn=01604953\&volume=20\&issue=2\&articleid=1455219\&show=pdf

(C) 2001, MCB University Press. All rights reserved.

\title{
(M)other tongue: a selected annotated bibliography of world "Englishes"
}

\author{
Miriam Conteh-Morgan
}

Miriam Conteh-Morgan is Reference Librarian at Ohio State University Libraries. Columbus. Ohio. USA.

\begin{abstract}
The cultures and languages of Africa and Asia have had an immense impact on the use of English language there. Awareness of this impact led to a recognition of new, indigenized varieties known collectively as world "Englishes". They display a number of linguistic and pragmatic patterns different from native varieties, and these have been the subject of much scholarly activity over the last 30 years. This selected bibliography attempts to introduce the literature to librarians, other than English, linguistics, or education selectors. Interdisciplinary in nature, the study of world "Englishes" has implications for research in the history, culture, sociology, and politics of these regions. Selectors in these subjects and general reference librarians should therefore know more about world "Englishes" to provide more useful assistance to patrons.
\end{abstract}

That English is no longer seen as the preserve of native speakers is a "feat" that no other major world language has achieved. The original "inner circle" of native speakers has spawned an "outer circle" of users of English in former British and American colonies (Kachru, 1996). The majority of these countries still use English as an official language, and consider it their second language. In addition, there is the "expanding circle", constituting countries like China and Japan, where English has acquired the status of the most favored foreign language and is widely taught in schools. It is the users in the outer circle, however, that have had a great impact on English in recent decades and precipitated paradigm shifts.

There has been a change in attitudes toward non-native "Englishes". Traditionally, differences in the use of English by second language speakers have been characterized by linguists as deviant, incorrect, or sub-standard, a conservative view that suggests linguistic purism. However, since the 1970s, with the steady growth of scholarly material on the new "Englishes", and creative works by their speakers (such as Wole Soyinka who won the 1986 Nobel Literature Prize), non-native "Englishes" can no longer be ignored.

Acceptance consequently gave rise to new forms of linguistic analyses. The new emphasis was on the functions of English in pragmatic contexts, rather than on "erroneous" use; for English, in its new cultural contexts, was being infused with, for example, "the tempo of Indian life" (Rao, 1938), or made to "carry the weight of [the] African experience" (Achebe, 1965). Inherent in this approach was the questioning of the hegemony of native varieties and the "liberating" of English.

This annotated bibliography, covering the 1980s and 1990s, comprises books on African and Asian Englishes. Scholarly articles are excluded, but major journals devoted exclusively to world "Englishes" are listed. 
While linguistics, education, and English selectors may be aware of this academic area, other selectors need to be made current with it because it touches on many other disciplines cultural studies, area studies, communication, sociology, history and politics. Awareness of this area would also help general reference librarians. Since most of these subject areas are physically housed together in many campus libraries, it is not inconceivable for questions on world "Englishes", ranging from undergraduates looking for information on intercultural communication to graduate students doing literature review searches on cross-cultural education or post-colonialism, to find their way to the reference desk.

The "nativizing" of English will continue, and these variant forms will continue to generate scholarly interest. Librarians must, therefore, be ready to provide access to them.

\title{
Reference works
}

\author{
Branford, Jean and Branford, William (1991) \\ A Dictionary of South African English, Oxford University Press, Cape Town
}

This is a revised and updated edition of the 1978 dictionary, enlarged to include new items from all speakers of English in South Africa.

Glauser, Beat, Schneider, Edgar W. and Görlach, Manfred (1993)

A New Bibliography of Writings on Varieties of English, 1984-1992/3, John Benjamins, Amsterdam, Philadelphia, PA

This work, the second in the chronological series, lists 2,800 entries selected from journals, monographs and $\mathrm{PhD}$ theses. Sections are arranged according to regions: the UK and Ireland, USA and Canada, the rest of the world (see also Viereck et al, below).

Silva, Penny et al. (Eds) (1996)

A Dictionary of South African English on Historical Principles, Oxford University Press, Oxford

Beginning as a project at Rhodes University, South Africa, in 1968 to collect examples of English usage, this dictionary now has 5,000 entries. It also includes etymologies, quotations, and encyclopedic notes.

\section{Todd, Loreto and Hancock, Ian}

International English Usage (1986), Croom Helm, London

An encyclopedic reference book on English as used around the world. It also provides definitions and etymologies. Categories of terms include prejudiced and popular terms, and stylistic variation.

Viereck, Wolfgang, Schneider, Edgar W. and Görlach, Manfred (1984)

A Bibliography of Writings on Varieties of English, 1965-1983, John Benjamins, Amsterdam, Philadelphia, PA

A total of 4,200 entries covering three areas: the UK and Ireland, the USA and Canada, and 
others where English is used. Also includes entries on pidgins and Creoles in English-speaking countries.

\section{General titles}

\section{Bailey, Richard W. and Görlach, Manfred (1982)}

English as a World Language, University of Michigan, Ann Arbor, MI

This is one of the earliest works that tried to bring together in a single volume a discussion of English around the world. Chapters focus on specific countries Scotland, Ireland, Wales, South Africa, and the USA and on larger geographical areas like (West and East) Africa, the Caribbean, and South Asia. Includes maps and phonetic charts.

Brumfit, Christopher (Ed.) (1982)

English for International Communication, Oxford, Pergamon Press, New York, NY

This is a collection of papers initially presented at the 1980 English-Speaking Union conference in London. Definitions of "English as an international language", and the need for establishing national norms are debated.

Crystal, David (1997)

English as a Global Language, Cambridge University Press, Cambridge

Crystal defines "global English", states why English has acquired this status, and describes the historical context of its growth and its legacy. Whether or not English will continue to dominate is another issue discussed.

Fishman, Joshua A., Conrad, Andrew W. and Rubal-Lopez, Alma (Eds) (1996)

Post-imperial English: Status Change in Former British and American Colonies, 1940-1990, Morton de Gruyer, Berlin, New York, NY

The central focus is on English in 20 countries which were under British or American political influence. The chapters explore the evolution of English in form, function, and role over a 50year period, and try to determine whether English is spreading even after colonialism and if so, the driving forces behind the spread, and the relationship between the functions of the new and native varieties.

Garcia, Ofelia and Otheguy, Ricardo (Eds) (1989)

English Across Cultures, Cultures across English, Mouton de Gruyter, Berlin, New York, NY

The articles explore the socio-cultural, socio-political, sociolinguistic and, socio-psychological aspects of communication in English by both native and non-native speakers.

Görlach, Manfred (1991)

Englishes: Studies in Varieties of English, John Benjamins, Philadelphia, PA 
The author brings together a selection of his articles on English as a World Language (EWL) written between 1984 and 1988. Some articles discuss the development of varieties, and the lexicographic problems of new Englishes. He also discusses issues of identity, standards, and dialects in Canada, Australia, and Jamaica. Similar collections followed in 1995 and 1998.

Kachru, Braj B. (1986)

The Alchemy of English: The Spread, Functions, and Models of Non-native Englishes, Pergammon Press, Oxford

In this collection of revised papers, Kachru defines nativized varieties and assesses their growth. He describes the norms and models for standardizing new Englishes, contact situations and their impact on language, and the creative efforts of non-native English authors.

McArthur, Tom (1998)

The English Languages, Cambridge University Press, Cambridge

The author presents his own model of new Englishes, relating it to Kachru's and Görlach's. Also discusses pidgins and Creoles, lects and varieties, and standardization.

Platt, John, Weber, Heidi and Lian, Ho Mian (1984)

The New Englishes, Routledge and Kegan Paul, London, Boston, MA

Phonetic, semantic, grammatical, and sociolinguistic features of the new Englishes are discussed, as are their uses in literature, and impact on teaching. Detailed examples are drawn from a variety of countries and contexts.

Pride, John (Ed.) (1982)

New Englishes, M.A. Rowley, Newbury House

The notions of bilingualism and biculturalism, and the development of regional standards in different societies and regions are examined. The authors also explore the use and function of English in non-native regions.

Schneider, Edgar W. (Ed.) (1997)

Englishes Around the World: Studies in Honour of Manfred Görlach, John Benjamins, Philadelphia, PA

This is a festschrift marking the 60th birthday of Görlach, "the founder of the study of English in a worldwide context as a scholarly field" (Schneider, p. 3). The worldwide-ness is represented in the wide geographic scope of the articles: Caribbean, Africa, Asia, and Oceania. Topics covered include discourse, error and text analysis, and the form and function of English in various regions and contexts.

Smith, Larry E. (Ed.) (1983)

Readings in English as an International Language, Pergamon Press, Oxford, New York, NY 
This collection of 16 previously-published articles offers definitions of English in an international context. The articles also raise the issues of cross-intelligibility, standardization, discourse, and the teaching of non-native Englishes.

Smith, Larry E. and Forman, Michael L. (1997)

World Englishes 2000, College of Languages, Linguistics and Literature, University of Hawaii, Honolulu, HI

These are a selection of papers presented at the 1996 International Conference of the International Association for World Englishes held in Honolulu. Some of the 13 articles call for a paradigm shift in research and teacher preparation, and for breaking the hegemony of native varieties. Others explore the interface between culture and language especially in Asia and South Africa, and the role of contact ecologies in creole formation.

Trudgill, Peter and Hannah, Jean (1985)

International English: A Guide to Varieties of Standard English, Edward Arnold, London

A description of the differences between non-native varieties of English and the native ones of Australasia, South Africa, North America, and Scotland and Ireland (areas where it was superimposed to become native) is given. The main emphasis is on pronunciation differences, but there are a few examples of lexical variation.

\section{Africa}

Bamgbose, Ayo, Banjo, Ayo and Thomas, Andrew (Eds) (1997)

New Englishes: A West African Perspective, Africa World Press, Trenton, NJ

The collection represents selected papers presented at a conference marking 50 years of the British Council in Nigeria in 1993. Papers are arranged under four headings: language policy, pedagogy, creative writing and corpus research. While the title suggests a wider regional scope, more than half 13 of the 21 articles - are on English in Nigeria.

De Klerk, Vivian (Ed.) (1996)

Focus on South Africa, John Benjamins, Amsterdam, Philadelphia, PA

These essays throw the spotlight on the various aspects of English in South Africa. The first four sections provide insights into the history, pan-ethnic varieties, and issues of standardization and education. The last section situates this variety in a regional context by examining the Englishes of Swaziland, Zambia, Malawi and Zimbabwe.

Mesthrie, Rajend (1992)

English in Language Shift: The History, Structure, and Sociolinguistics of South African Indian English, Cambridge University, Cambridge

Focusing on a dialect of South African English, its impact and its users, the book describes how 
South Africans of Indian origin acquire their variety of English. The variety is also compared with others in South Africa and India.

Schmied, Josef (Ed.) (1989; 1992)

English in East and Central Africa, Vols 1 and 2. Bayreuth University, Bayreuth

The first volume has four chapters: two essays on English in Africa and the Indian sub-continent, others on Kenyan students' attitude to English, and pedagogical issues in Zambia. Volume 2 holds more essays on teaching and assessment in Tanzania, South Africa and Zambia, grammar in Cameroonian English, and Kenyan popular literature. This makes the title rather misleading as no central African countries are represented. Schmied's other work, English in Africa (1991), is the first comprehensive study of English on the continent its history, use, linguistic forms, and functions, and attitudes toward it. Examples are drawn from various countries, providing a broad coverage not found in many other works.

\section{Asia}

Baumgardner, Robert J. (1996)

South Asian English: Structure, Use, and Users, University of Illinois Press, Urbana, IL

The chapters provide insights into the history, status, functions, and structure of English in the largest non-native speaking region of the world, South Asia. Two chapters are devoted to the study of English in Nepal, an area on which there are hardly any studies.

Foley, J. A. (Ed.) (1998)

English in New Cultural Contexts: Reflections from Singapore, Oxford University Press, Oxford, New York, NY

Articles discuss the historical development and give linguistic analyses of Singaporean English. Also explores the implications for teaching English in Singapore.

\section{Gupta, Anthea Fraser (1994)}

The Step-tongue: Children's English in Singapore, Multilingual Matters, Clevedon

The main theme of the book is the acquisition of aspects of English by bilingual (EnglishChinese) children. There is also a historical sketch of English in Singapore, a profile of Singapore speakers of English, and a discussion of English as a language of education.

Gupta, R.S. and Kapoor, Kapil (Eds) (1991)

English in India, Academic Foundation, Delhi

English as used in India is analyzed from a number of perspectives: historical, sociolinguistic, pedagogical, forms and range of uses. The impact of English and Indian languages on each other and on creative writing is also analyzed. 
Ho, Mian Lian and Piatt, John L. (1993)

Dynamics of a Contact Continuum: Singaporean English, Clarendon, Oxford

The book traces the development of Singaporean English. The main emphasis is on grammatical aspects (nouns and verbs) of this variety of English.

Kachru, Braj B. (1983)

The Indianization of English: The English Language in India, Oxford University Press, Dehli, New York, NY

Kachru brings together studies written over a period of 20 years. The chapters trace the cultural and linguistic processes that gave rise to the development of this distinct variety of English. The last chapter situates Indian English in the context of the wider phenomenon of Englishization in other parts of the world.

Krishnaswamy, N. and Burde, Archana S. (1998)

The Politics of Indians' English: Linguistic Colonialism and the Expanding English Empire, Oxford University, New York, NY

The authors argue that the core literature on Indian English does not make a clear distinction between the spoken and written forms, and that examples drawn mainly from written creative works are not representative of the spoken forms. They analyze data going back to the seventeenth century to show that the basic structure of Indians' English has remained unchanged, despite the new uses to which the language is being put.

Newbrook, Mark (Ed.) (1987)

Aspects of the Syntax of Educated Singaporean English: Attitudes, Beliefs, and Usage, P. Lang, Frankfurt am Main, New York, NY

Reports on dialectological and theoretical research carried out by the author, in collaboration with other researchers. Studies focus on educated users, their perception of and attitudes to both Singaporean and British Englishes.

Pennycook, Alastair (1994)

The Cultural Politics of English as an International Language, Longman, Harlow, New York, $\mathrm{NY}$

Pennycook uses Singapore and Malaysia as examples to discuss the social prestige of English during colonialism, its role and uses in the postcolonial era, and the growing English teaching "industry" in South East Asia.

\section{Doctoral dissertations}

\section{Amoabeng, Kwaku (1986)}

The English Language in Ghana: A Comprehensive, Annotated Bibliography, State University of New York at Stony Brook, Stony Brook, NY 
The works in this annotated bibliography on the use of English in Ghana are drawn from scholarly, professional, educational, and journalistic sources. Time coverage is wide -from the earliest British contacts to the end of the 1970s.

\section{Ayyar, Indira (1993)}

Language Crossover in the Syntax of Spoken Indian English, State University of New York at Stony Brook, Stony Brook, NY

Analyzes conversations of Tamil speakers of Indian English for recurrent patterns, and these are compared with those of native speakers of American English. The patterns are seen as a result of first language crossovers.

\section{Brutt-Griffler, Janina (1998)}

The Development of English as an International Langauge: A Theory of World Language, Ohio State University, Columbus, $\mathrm{OH}$

Attempts to provide a comprehensive framework for analyzing the sociohistorical development of English as an international language (EIL) by integrating theories of language change and spread to produce a "world language theory". The study also looks at how EIL impacts crosscultural pedagogy.

\section{Chisanga, Teresa (1987)}

An Investigation into the Form and Function of Educated English in Zambia as a Possible Indigenized Non-native Variety, University of York, York

A contrastive analysis of British Standard English and the English of educated Zambians is done. Conclusion reached is that there are some variations between the two.

\section{Chisimba, Maurice (1984)}

African Varieties of English: Text in Context, University of Illinois at Urbana-Champaign, Urbana-Champaign, IL

This sociolinguistic study of the discoursal patterns, strategies, and structure of varieties of English in Africa emphasizes the social markers of speech. Chisamba argues that socio-cultural setting should form part of the discussions on English as a second language.

\section{Gunesekera, Manique (1989)}

Discourse Genres in English Newspapers of Singapore, South India and Sri Lanka, University of Michigan, Ann Arbor, MI

Lead stories and editorials taken from the "quality English press" of the three regions are compared and contrasted to determine if there is evidence of the use of a new English. Results show a difference in rationale, structure, and language use of the genres, and very little evidence of new English usage. 


\section{Jung, Kyu (1998) \\ Contact and Convergence of English in Korea. University of Illinois at Urbana-Champaign, Urbana-Champaign, IL}

The study discusses the impact of English in Korea by examining the morphosyntax and phonology of English loanwords in advertising, code alteration in soap operas, and modal verbs in Korean English-language newspapers.

\section{Khan, Farhat (1989)}

Linguistic Variation in Indian English: A Sociolinguistic Study, University of Reading, Reading

Data collected from interviews with 44 speakers of Indian English are analyzed to establish what linguistic constraints affect phonological variation in Indian English, and whether there are social indicators marking these variations.

\section{Magura, Benjamin (1984)}

Style and Meaning in African English: A Sociolinguistic Analysis of South African and Zimbabwean English, University of Illinois at Urbana-Champaign, Urbana-Champaign, IL

Magura uses literary works to exemplify the three social factors affecting the development of the English used by black Africans in South Africa and Zimbabwe, and the underlying linguistic processes at work. Concludes that blacks' English differs from the standard because it has developed its own unique style and meaning.

\section{Moody, Andrew (1997)}

The Status of Language Change in Hong Kong English, University of Kansas, Lawrence, KS

E-mail messages of four speakers of Hong Kong English are analyzed for underlying patterns of communication. Results reveal two levels: use of indigenized norms when the participants share the same language background, and non-indigenized ones in inter-ethnic communication. This shift reflects the use of Hong Kong norms in the process of nativizing English.

\section{Nelson, Cecil (1984)}

Intelligibility: The Case of Non-native Varieties of English, University of Illinois at UrbanaChampaign, Urbana-Champaign, IL

Analyzes a text by Indian writer, Raja Rao, and tries to validate the existence of new Englishes. An empirical study of the interstress timing patterns of Indian and American English speakers is undertaken, with the conclusion that there is no significant difference between the two varieties to impede mutual intelligibility.

\section{Nyaggah, Lynette (1990)}

Cross-Linguistic Influence in Kenyan English: The Impact of Swahili and Kikuyu on Syntax, University of California, Los Angeles, CA 
Four syntactic structures are examined in the speech of Kenyan English speakers to determine the influence of their first language on their English. Concludes that elements of the Bantu Animacy Heirarchy found in both Swahili and Kikuyu are evident in the English syntactic structures of the speakers.

\section{Peyawary, Ahmad (1998)}

The Core Vocabulary of International English: A Corpus Approach, University of Manitoba, Winnipeg

US, British and Indian varieties of English are investigated to determine the existence of a common core vocabulary. By applying a statistical method capable of evaluating language corpora, the results show that there is a boundary between the syntactic categories of core English and US, British and Indian Englishes.

\section{Journals}

English Today: The International Review of the English Language (1985-), Cambridge University Press, Cambridge, New York, NY, ISSN 0266-0784

Edited by Tom McArthur and published quarterly, this journal covers a broad range of topics and countries. Combines scholarly articles with features on usage, research updates, and crossword puzzles.

English World-Wide: A Journal of Varieties of English (1980-), John Benjamins, Amsterdam, (formerly by Julius Groos Verlag, Heidelberg) ISSN 0172-8865

Originally edited by Manfred Görlach, now by Edgar Schneider. Appears twice per year, with an average of five articles per issue. Includes research studies, annotated bibliographies, and book reviews.

World Englishes: Journal of English as an International and Intranational Language (1985-), Basil Blackwell, Oxford (originally World Language English, Pergamon, Oxford) ISSN 08832919

Edited by Braj Kachru and Larry Smith, the journal is published three times a year, averaging seven articles per issue. The subtitle suggests an emphasis on local and international communication. It occasionally has special issues, such as one on Ebonics.

\section{References}

Achebe, C. (1965), "English and the African writer", Transition, Vol. 18.

Kachru, B.B. (1996), "Norms, models, and identities", The Language Teacher Online, available from: http://langue.hyper.chubu.ac.jp/jalt/pub/tlt/ 96/oct/englishes.html (accessed 26 November 2000).

Rao, R. (1938), Kanthapura, G. Allen, London. 